\title{
(Un)shared memory: European Parliament and EU Remembrance Day for Victims of Terrorism
}

Ana Milošević

Leuven Institute of Criminology, KU Leuven, Herbert Hooverplein 10, 3000

Leuven. Belgium

ana.milosevic@kuleuven.be

Gérôme Truc

Institut des sciences sociales du politique, Université Paris Nanterre, 200 avenue de la République. 92001 Nanterre, France

Gerome.TRUC@cnrs.fr

\begin{abstract}
This article explores the role of the European Parliament in fostering and promoting shared remembrance of the victims of terrorist attacks. First, we discuss the origins of the EU Remembrance Day for Victims of Terrorism, established by the EP on the very day of the Madrid bombings, on March 11, 2004, and the earlier stages of its institutionalisation. We scrutinize the rationale for this transnational day of remembrance, the main actors involved, and the tools used to promote it. Then, we examine the effectiveness of this promoted 'shared' remembrance by analysing how the EU and its member states commemorate March 11th. It appears that, while the EP's role evolved from a norm setter to a passive actor, the EU's Remembrance Day remains for now 'European' essentially by name.
\end{abstract}

Keywords: EU; terrorism; European memory; victims; commemoration; memory politics 


\section{Une mémoire partagée ? Le Parlement européen et la journée européenne en mémoire des victimes du terrorisme}

Cet article explore la façon dont le Parlement européen encourage et promeut au sein de l'UE une commémoration transnationale des victimes d'attaques terroristes. Nous revenons sur les origines de la Journée européenne du souvenir des victimes du terrorisme, instituée par le PE le jour même des attentats de Madrid, le 11 mars 2004, et sur les premières étapes de son institutionnalisation. Nous examinons aussi les raisons mises en avant pour la justifier, les autres acteurs qu'elle implique, et les outils utilisés pour la promouvoir. Enfin, nous interrogeons l'effectivité de cette mémoire se voulant « partagée » au niveau européen en étudiant la manière dont l'UE et ses États membres commémorent le 11 mars. Il apparâit ainsi que, si le rôle du Parlement européen a évolué, passant d'un rôle normatif à un rôle passif, cette journée de commémoration continue à n'avoir d'«européenne » essentiellement que le nom.

Mots-clés : Union européenne ; terrorisme ; mémoire européenne ; victimes ; commémoration; politiques mémorielles 


\section{Introduction}

Terrorism is a complex symbolic act that resorts to violence with aim of creating both a psychological and physical impact on individuals and societies. The victims of terrorism experience such violence and "serve as the conduits to the intended and broader audience, [...] government $[\mathrm{s}]$ or the wider population" (Lynch and Argomaniz, 2015, 1). How to remember such violence and its victims? Going beyond strictly locally and nationally grounded memorial responses in the aftermath of terrorist attacks, in this paper, we look at how victims of terrorism are represented in the EU memory politics, policies and mnemonic practices.

The goals assigned to memorialisation processes are multi-faceted. They are geared not only towards the past (acknowledgement, recognition, honoring victims), but equally pertinent to the present (reconciliation, truth and justiceseeking, resilience building) and the future (violence prevention, awarenessraising, learning from the past). The concept of the 'duty of remembrance' of mass crimes, such as the destruction of European Jews by the Nazis, asserts the legitimacy of seeking reparation and drawing lessons from the past (see Gensburger and Lavabre, 2004; Gensburger and Lefranc, 2020). This understanding that memorialisation should be a means to combating injustice and promoting reconciliation permeates EU's memory politics.

EU memory politics is reflective of jointly forged political stances on the past, showing that European histories and hence experiences are entangled. As such, a shared memory - the lowest common denominator of those (different) pasts - is identified as a key to forging a sense of belonging to a united Europe, able to underpin its legitimacy and identity-building efforts (Gensburger and Lavabre, 2012; Calligaro and Foret, 2012). While such cosmopolitan approaches to EU memory prescribe ethical and moral templates in confronting the matters of the past (Levy and Sznaider, 2002), the EU - a transnational mnemonic arena - more often serves as a political opportunity structure. Various stakeholders (i.e. member states, political parties, formal and informal groups, like-minded individuals) seek to "upload" their own views and narratives about the past (Milošević and Trošt, 
2020; see Rosoux, 2003; Littoz-Monnet, 2012; Mälksoo, 2009) deemed important for their own nationhood (Anderson, 2006; Connerton, 1989).

In the process of European Integration EU memory framework has emerged "consisting of a series of policies, resolutions and decisions made primarily by the European Parliament (EP) that both reflects and guides collective political attitudes of the EU towards the past" (Milošević and Touquet, 2018, 309). While recent studies examine the policy making process in the EP (such as this special issue) describing the (f)actors that guide memory adjustments, formation, dissemination and outcomes of EU memory policies, in this study we focus on a particular aspect of this framework - the observance of EU days of remembrance. These days of remembrance are "meant for EU citizens to become more selfaware of the collective European history, particularly when that history is traumatic" (Manners, 2011, 257-258). It is through this lens that we analyse the origins and development of the EU Day for Victims of Terrorism, established by the European Parliament on the very day of the Madrid bombings (March 11th, 2004). We probe the transnational character of this "European commemoration" taken it to be a "political mobilisation of symbols and narratives, by the EU, to awaken and preserve beliefs and feelings about transnational past of Europe" (Milošević, 2019, 210).

We draw from the emergent field of sociology of terror attacks (Truc, 2018; 2019) as well as perspectives from memory and EU studies to analyse the genesis and implementation of the EU Day of Remembrance for terrorism victims. Our analysis begins by scrutinising the role of the European Parliament in establishing this date. We ask who the main actors are, what roles do they assign to memorialisation and what mnemonic tools do they use to promote it. Our analytical approach will encompass the agency of key stakeholders: the EU, national governments, victims' organisations and (broadly) victims themselves. Finally, we examine the effectiveness of this promoted 'shared' remembrance by looking at how the EU and its member states commemorate March 11th. Material for our analysis is taken from our two research projects: METEUR Memorialising terror: Remembrance and Social Recovery after Terrorist Attacks 
(Author 1) and REAT - The Social Reaction to Terrorist Attacks (Author 2). ${ }^{1}$ Data has been collected through interviewing, ethnographic and archival work, in various capital cities concerned by the memorialisation of terror attacks around Europe, in particular Madrid, Paris and Brussels. The data concerning the 2019 and 2020 commemorations in Brussels and Paris come from participant observation of Author 2 and her collaboration with the European Commission (DG Home Affairs) in her capacity as an adviser on organisation and implementation of the EU Day of Remembrance for terrorism victims. This ethnographic approach involved active participation in the group in order to gain an insider's perspective and to have experiences similar to the group members. As such, an account of the EC's role in remembering victims of terrorism is based on participation, interviews with group members, and an analysis of group documents for which the researcher has a permission to use.

\section{The origins of the EU Remembrance Day for Victims of Terrorism: EP as memory actor}

\section{An exceptional case of immediate memorialisation}

The role of the European Parliament in building EU's memory framework and, within it, in symbolically honoring the victims of terrorism, is generally one of a norm-setter (Milošević and Touquet, 2018). Through policy making process and mnemonic tools, the EP provides the initial impulse to delineate joint EU attitudes on the matters of the past that are often out of the jurisdiction of MEPs and thus could not be voted about differently. For instance, the EP voted a resolution to symbolically honor the victims of Holodomor - artificial famine in the 1930s Ukraine (EP, 2008) or a number of resolutions on the Armenian genocide (EP, 2015). These soft laws are, as the Introduction to this special issue shows, a

\footnotetext{
1 METEUR project is supported by the Special Research Fund (BOF) at the KU Leuven in Belgium; REAT project has been funded from 2016 to 2018 by the French National Center for Scientific Research (CNRS). In the framework of these research projects and hence our work with victims of terrorism, special protocols were designed to ensure compliance with ethical principles especially the following: respecting human dignity and integrity, ensuring honesty and transparency towards research subjects, getting free and informed consent, protecting the vulnerable, ensuring confidentiality, promoting justice and inclusiveness, sharing the benefits with disadvantaged populations. As researchers working with vulnerable populations, we are cognisant of the fact that the privacy of the subjects, in certain cases, may already have been breached by the media or others who have made their names and personal identifiers public knowledge. In this study, we use personal identifiers only when referring to the victims that have either given their written consent to participate in one of our research projects or have delivered their testimony in a public event.
} 
product of continuous negotiation, bargaining, consensus making and trade-offs between political leaders, party groups, and individual members of the Parliament, that often work hand in hand with civil society, museums, historians, and victims' groups. The resolution establishing the day of remembrance for terrorism victims is no exception. Voted in the very morning of the attacks in Madrid, it had actually been crafted much earlier. ${ }^{2}$

The motion for this resolution tabled two days earlier by José Ribeiro e Castro (member of the EPP, elected to the European Parliament during 10 years, from November 1999 to July 2009, who was also president of the Portuguese People's Party from 2005 to 2007) was based on his report on "the progress made in 2003 in the creation of an area of freedom, security and justice" in Europe - a creation that was put on the European agenda by the Treaty of Amsterdam in 1999 and then strongly favored by the post-11-September context (Bigo, Bonelli and Deltombe, 2008; Monar, 2009). In this motion, ${ }^{3}$ the proposal was to commemorate from now on the victims of terrorism every 11 September, and this is what the MEPs were to debate on Thursday 11 March 2004, among other subjects. However, that morning in Madrid, ten bombs exploded in suburban trains at rush hour, killing 192 people and injuring some 2,000, the worst attack ever on European soil, that a number of politicians and journalists quickly qualified as "European 11th September" (Truc, 2018, 39-48).

At the opening of the parliamentary session, the President of the European parliament, Hans-Gert Pöttering started by making a statement condemning in the most vigorous terms the terrorist attacks in Madrid. He expressed his condolences to the families of the victims and the Spanish people and explained that orders had been given that the Spanish and European flags be flown at half-mast and asked the Parliament to observe a minute's silence. A few moments later, it was time to debate the motion for a resolution to establish a day of remembrance in memory

\footnotetext{
2 In the following, we take up and summarize elements already exposed in Gérôme Truc, « Aux victimes du terrorisme, l'Europe reconnaissante ? Portée et limites de la Journée européenne en mémoire des victimes du terrorisme », Politique européenne, 2012, n 37, p. 132-154.

3 EP. 2004. Motion for a resolution (B5-0148/2004). Source :

$<$ https://www.europarl.europa.eu/sides/getDoc.do?type=MOTION\&reference=B5-20040148\&language $=\mathrm{EN}>$.

6
} 
of the victims of terrorism. While events were still unfolding in Madrid and the final toll of the attacks was not yet known, Jorge Salvador Hernández Mollar, a Spanish politician elected to the European Parliament from November 1995 to July 2004, proposed then, in view of the circumstances, to table an oral amendment to the resolution in order to replace the date of 11 September with 11 March. Ribeiro e Castro supported the request, pointing out that the proposition to establish the commemorative day on 11 September had not met with unanimous approval and that "nobody would understand it if - since, by sheer coincidence, we have to vote on this today - we did not choose 11 March to pay our respects to present and future victims, and also past ones, by choosing a European day". 4

A debate then emerged in the assembly, as the initial idea of this European day of commemoration was also that it could quickly be extended to a global scale which might be less obvious by fixing it on 11 March rather than 11 September. The President, however, put a swift end to it, lest "the dignity of this House [...] be sullied in any way by a debate on dates, when so many people are facing such massive losses today". 5 The resolution was therefore adopted without further discussion, and then forwarded to the European Council that adopted it by December of the same year (2004), so that the first official EU Remembrance Day for Victims of Terrorism could be held on the first anniversary of the Madrid bombings, on March 11, 2005 - an unusual case of 'immediate memorialisation' at an institutional level (Truc, 2017).

\section{The Spanish influence on an EP resolution}

Adopting this remembrance day was a way for the European Union to express its solidarity with the victims of terrorism and to provide them with a form of symbolic recognition, while condemning acts of terrorism as "one of the most serious violations of the universal values of human dignity, freedom, equality and solidarity, and enjoyment of human rights and fundamental freedoms on which

4 Debates at European Parliament, 11 mars 2004, before the vote on the motion for a resolution B50148/2004 tabled by the Committee on Citizens' Freedoms and Rights, Justice and Home Affairs, on progress towards an area of freedom, security and justice (2003): <http://www.europarl.europa.eu/sides/getDoc.do?pubRef=-//EP//TEXT+CRE+20040311+ITEM$006+\mathrm{DOC}+\mathrm{XML}+\mathrm{V} 0 / / \mathrm{EN} \&$ language $=\mathrm{EN}>$. 5 Ibid. 
the Union is founded". 6 In the resolution adopted on March 11, 2004, one can read indeed:

"[The European Parliament] declares its support for and solidarity with the victims of terrorism and their families, as well as with the organisations and communities caring for them; for this reason recommends that the European Union take the initiative at world level to establish an International Day of the Victims of Terrorism and, to this end, calls on the Commission to forward to the JHA Council immediately a proposal for a European day commemorating the victims of terrorism, and proposes 11 March as the date for it."

Investigating how the EU day for victims of terrorism was framed in its early years, Truc $(2012,136)$ highlights that EU institutions evoked the sacrifice "of those who spilt their blood for their attachment to European democracy", "freedom" and other "European values". This nationalistic framing indicates that the resolution establishing the EU Remembrance Day for Victims of Terrorism served, in practical terms, as a spin-off to the security agenda pursued by the EPP - and more specifically by its Spanish members, under the influence of the victims of ETA.

Following on from the Aznar Protocol in the 1990s, the September 11 attacks gave Spain the opportunity to place the fight against ETA in the framework of the "war on terrorism" waged on a global scale by the United States and its Western allies (Guittet, 2006). Thus, "the list of 'terrorist persons, groups or entities' defined by the European Union - then under the Spanish presidency - after the shock of 11 September 2001, begins with a nominal list of individuals suspected of belonging to Euskadi Ta Askatasuna (ETA)" (Bonelli, 2005, 104). A movement of generalisation then began, making it possible to equate the victims of Basque separatism with those of international jihadism, and thus to give the generic category ${ }^{8}$ of 'victims of terrorism' a consistency at the European level that

6 Directive (EU) 2017/541 of the European Parliament and of the Council of 15 March 2017 on combating terrorism and replacing Council Framework Decision 2002/475/JHA and amending Council Decision 2005/671/JHA OJ L 88, 31.3.2017, p. 6-21.

7 OJ C 102E, 28.4.2004, p. 819-828 (821), available on line:

$<$ https://www.europarl.europa.eu/sides/getDoc.do?type=TA\&reference=P5-TA-2004-0179\&language=EN>. 8 Whether the victims of terrorism represent or not a specific category of "victims" for European policy makers remains an open question. Some policy papers even draw direct comparison between preserving the memory of the terrorist victimhood and the one of the Second World War: "As with Holocaust survivors, the aim is for non-repetition, that this should not happen again" (RAN, 2018,1). 
it did not have until then (Lynch and Argomaniz, 2015). Interventions by members of the EPP in the European Parliament clearly demonstrate this. On 11 February 2004, for example, a Spanish MEP, Marcelino Oreja Arburúa, declares:

"I come from a country suffering the scourge of terrorism. In my homeland, some of the principles laid down in Article 6 are flouted. The terrorist group ETA deprives many of my fellow citizens of freedom of speech, freedom of action, and freedom to engage in politics. ETA and its followers restrict our liberty and threaten the rule of law. The scourge of terrorism can only be eliminated by working within the rule of law, in cooperation with the judicial authorities and the police. In this day and age, terrorism can no longer be deemed a local problem. It is a global threat to us all, the European Union included ${ }^{9,},{ }^{10}$

The post-September 11th context thus enabled associations of victims of terrorism to achieve unprecedented political influence. This is as true in the United States (Hoffman and Kasupski, 2007) as it is in Europe, where this new situation has particularly served the cause of Spanish victims of ETA. The association "Victimas del Terrorismo" (AVT), founded in 1981, which had already become an important lobby of the Spanish right during the 1990s, then sought to extend its action at the European level in favour of a tougher fight against terrorism and a better recognition of the victims of terrorism, targeting the MEPs of the EPP, who started to be the majority-group in the EP from the 1999 elections. The adoption of the Remembrance Day for Victims of Terrorism very clearly bears the mark of its influence: on March 11, 2004, two representatives of the association were by the way present in the EP to attend the session. ${ }^{11}$

But if the AVT's influence is quite evident here, it is also because, when the MEPs proceeded to vote on March 11, 2004 morning, there was no doubt in their minds that the attacks that had just taken place in Madrid were carried out by ETA, as the first information from Spain indicated at the time. The MEP Jorge Salvador

9 Debates at European Parliament (on the Progress in implementing the area of freedom, security and justice (AFSJ) in 2003), 11 February 2004, OJ Edition, available online: <https://www.europarl.europa.eu/sides/getDoc.do?pubRef=-//EP//TEXT+CRE+20040211+ITEM$001+\mathrm{DOC}+\mathrm{XML}+\mathrm{V} 0 / / \mathrm{EN}>$.

10 Debates at European Parliament (on the Progress in implementing the area of freedom, security and justice (AFSJ) in 2003), 11 February 2004, OJ Edition, available online: $<$ https://www.europarl.europa.eu/sides/getDoc.do?pubRef=-//EP//TEXT+CRE+20040211+ITEM$001+\mathrm{DOC}+\mathrm{XML}+\mathrm{V} 0 / / \mathrm{EN}>$.

11 As Ángeles Pedraza, then president of the AVT, recalled it for instance in a speech in Madrid on 11 March 2011. 
Hernández Mollar (EPP) said this explicitly when he asked to change the date of the Remembrance Day:

"By a fatal and terrible coincidence, on the very day on which we are calling for a European Day to commemorate these victims, the murderous terrorist group ETA has caused the condemnable massacre of more than 138 people and hundreds of injured at various points in Madrid." 12

It would soon become clear that the perpetrators are in fact Islamic terrorists, as confirmed by investigations later (Reinares, 2017). José Maria Aznar, then still at the head of the Spanish Government for a few days, and the elected representatives of the PP found it very difficult to admit this, which earned them a surprise defeat in the general elections of 14 March 2004 (Bali, 2007) and caused conspiracy theories to flourish in Spain for several years (Chueca, 2012). In any case, the creation of the EU Remembrance Day on the very morning of the attacks of 11 March 2004 relied also on a misunderstanding, which from the outset limited its scope, including in Spain.

A European Day of Remembrance European only by name?

While the proclaimed EU day in its inception recognized global importance of commemorating all victims of terrorism, it can be argued that for many years, March 11th remained mainly a Spanish affair. On the one hand, as we just saw, the chosen date and rationale for it are in direct link with the March 11, 2004 attacks in the Spanish capital. On the other, EU recognition of terrorism victimhood was particularly relevant for the Spanish victims of ETA. Hence, since its adoption, central to the observance of this European remembrance day has been the AVT, which organizes a ceremony every March 11th in Madrid (usually in the "Bosque del Recuerdo" situated in the Retiro Park) explicitly to celebrate it, and not only to mark the anniversary of the attacks, as do other associations of victims, but also of residents of the affected neighbourhoods, and the authorities (Truc and Sanchez-Carretero, 2019). The association also supports similar initiatives in other Spanish cities. 
These were, until very recently, the only events organized to observe the Remembrance Day outside the European institutions' premises in Brussels or Strasbourg. In the early years, the EP endeavoured to organize important events and to promote it as much as possible. During the first two years, several hundred teenagers 'of all nationalities' (but mostly recruited from European schools in Brussels) were invited to sit in the hemicycle in Strasbourg and observe a minute's silence in memory of the victims of terrorism, after the President and VicePresident of the Parliament had made a solemn declaration and a short film showing a portrait of a victim (of the Madrid bombings in the first year, of the 7 July 2005 attacks in London in the second) had been screened. But both of events received very modest media coverage, and remained largely unknown to Europeans (Truc, 2012a, 147).

A pan-European network of associations of victims of terrorism (NAVT) was created in 2007, funded by the European Commission, ${ }^{13}$ with the aim of stimulating a trans-national co-operation between associations of victims of terrorism and enhancing the representation of victims' interests at European Union level. This network tried to enhance the audience of the Remembrance Day in the following years by creating, for instance, ephemeral websites accessible on March 11th - in the main European languages. But with very little success: in 2008, this website counted only 200 visits 48 hours after the Remembrance Day, and barely yet 300 in 2009 (Truc, 2012a, 148). In 2009, the NAVT also launched an international call for young volunteers to raise awareness of the cause of victims of terrorism. Thus, students walked the streets of Madrid on March 11th to distribute T-shirts and badges with the NAVT logo. But far from coming from all over Europe, they were in fact all from Madrid universities. ${ }^{14}$ Actually, the NAVT was originally initiated and mainly run by Spanish associations, with headquarters in Madrid. This is why, basically, it did not change much in terms of the difficulties encountered in implementing the EU Remembrance Day for victims of terrorism outside Spain. At its fifth edition, on 11 March 2009, José Ribeiro e

13 Contract n $^{\circ}$ JLS/2008/E4/003-30-CE-0222844/00-11.

14 See the report "The Voice Of Victims in Europe: Networking for Victims Support”, NAVT, Madrid, mars

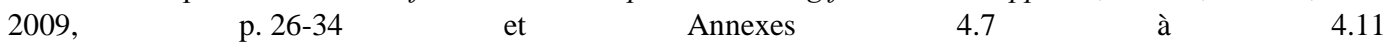
(<www.europeanvictims.net/images/blanca/ficheros/27_Report_11M_09.pdf〉). 
Castro, the father of the resolution adopted by the EP on the morning of the Madrid bombings, took the floor to explicitly deplore this state of affairs:

"Parliament has always faithfully celebrated this date, but unfortunately this date has not yet achieved the scope that it should have within the European institutions and Member States. I believe that the celebration of this date is one of our most important ways of paying tribute to the victims, as the President has done, but also of raising the level of public awareness. I know that there are some celebrations in Madrid today, but little else. I therefore call on the Commission and the Czech Presidency to ensure that all Member States appropriately celebrate this date in future."15 A year later, the MEP Diogo Feio, Ribeiro e Castro's successor ${ }^{16}$ in the EP, made the same observation and put a written question on the subject to the European Commission. In her answer to this question, Cécilia Malmström, European Commissioner for Home Affairs, merely recalled the European Commission's involvement in the ceremonies held in Brussels on March 11th, 2010 and pointed out that, for the rest, the organisation of commemorative ceremonies is the prerogative of national governments.

It has been therefore necessary to wait until the series of attacks endured by France in 2015-2016 for things to finally change. Following the attacks in Paris and Nice indeed, President Emmanuel Macron decided to create a Remembrance Day in France to honour the memory of all victims of terror attacks in France or against France since the mid-1970's, and to set this day on March 11th in line with the date already adopted by EU institutions. A grand ceremony was organised at the Place du Trocadéro, in Paris, on 11 March 2020, to mark the first occurrence of this new national Remembrance Day. Although Spain is therefore no longer the only European Union Member State to celebrate the memory of the victims of terrorism on March 11th, the commemoration created in France on this date is more of a national initiative than the implementation of the European

15 Debates at European Parliament, Wednesday, 11 March 2009 -Strasbourg, "Statements by the President", OJ edition: $\quad$ https://europarl.europa.eu/sides/getDoc.do?pubRef=//EP//TEXT+CRE+20090311+ITEM-002+DOC+XML+V0//EN>.

16 Both MEPs are Portuguese, and members of the CDS-PP. Diogo Feio was elected in 2009 (7th legislature, until 2015), after Ribeiro e Castro, a MEP from 1999 to 2009 (5th and 6th legislatures). 
remembrance policy at the French level. ${ }^{17}$ It is a national day in memory of (its) victims of terrorism that France now celebrates on March 11th, and not the EU Remembrance Day for Victims of Terrorism.

The King and Queen of Spain were invited in 2020 to take part in the Trocadero ceremony alongside President Macron, but it was precisely because 11 March is first and foremost the date of the Madrid bombings and on an inter-national basis, the Franco-Spanish friendship, rather than in the spirit of a trans-national remembrance, which would concern France, Spain and all the other EU Member States in the same way. A clear sign of demarcation: none of the high representatives of the EU had, in contrast, been invited to take part in this ceremony, neither the President of the European Council, nor the President of the European Commission, nor the President of the European Parliament. The event organised each year to mark the EU Remembrance Day for Victims of Terrorism by the EU authorities had this time been exceptionally relocated to Paris. It was held at UNESCO's premises in the morning, a few hours before the French government ceremony. ${ }^{18}$ However, these were two quite separate events, organised with a view to ensuring that those wishing to attend both could do so, but without there being any obligation for the international participants in the morning European ceremony to also take part in the afternoon Trocadero ceremony, organised first and foremost by and for French people.

This raises the question of the relationship between the national and European levels in the commemoration of the victims of terrorism in Europe, as well as the place of the European Parliament today in a policy of remembrance it initiated.

\section{From norm-setter to passive actor: EP and the EU memory policies for victims of terrorism}

17 While the French government chooses March 11th to commemorate, some of the victims' representatives and groups, such as the AfVT, were pushing for alternative dates, as September 19 (date of the attack against the DC-10 of UTA, in 1989, who caused the death of 170 individuals, including 54 French citizens).

18 One part of the attendees, mainly representatives of victims' organizations and victims themselves, were watching the UNESCO ceremony streamed in premises of the European Commission in Paris - due to minimalizing the risks related to the ongoing COVID-19 crisis. Field notes (Author 1), March 2020. 
Over the last 15 years the European Union has been annually observing the Day of Remembrance for victims of terrorism. Whereas the initial policy building impulse for the creation of such a commemorative event came from the European Parliament, its role in commemorative ceremonies has faded over time to become purely passive. For the occasion, a minute of silence is now observed during the plenary and/or at the beginning of committee meetings. In addition, individual MEPs sometimes host delegations, visitors or patronage side events in the EP buildings in Brussels and Strasbourg in memory of the victims. However, the main role in organising and promoting the EU day of remembrance has shifted entirely to the European Commission.

A joint statement that reflects the attitude of the EU - as a whole - is formalised in the name of all EU Institutions and member states (MS). In praxis, the management of the event is delegated to the DG Home Affairs - responsible for the fight against terrorism and radicalisation prevention. To this end, in 2011, the Commission launched Radicalisation awareness network (RAN). RAN gathers frontline practitioners from around Europe who work daily with radicalised, or those people who are vulnerable to radicalisation, - including members of associations of victims of terrorism already involved in the NAVT network.

The European Commission's 'Communication on Preventing Radicalisation to Terrorism and Violent Extremism' as well as the European Agenda on Security provides the policy framework to enact prevention policies. Funded by the Internal Security Fund, the RAN brings together also those who are not traditionally involved in counter-terrorism activities, such as teachers, youth workers, civil society representatives, local authorities and healthcare professionals. Across its 9 working groups, its mission is to support the EC and national governments with expertise and advice. 
The working group on Remembrance (RAN RvT) is composed of victims' groups, psychologists, academics and civil society representatives that work jointly to organise and implement the annual commemoration and encompassing, side events. Over the years, leadership of the group has been entrusted to French and Spanish victims' organisations identified by the EC representatives as key stakeholders and hence, representative of victims' voices. On a rolling basis, a number of new organisations are invited for consultations with the aim of diversifying the MS presence in the working group. The group's current objective is to maintain the network and to organise remembrance ceremonies in Brussels each year on March 11th.

Since its inception, the RAN RvT sought to include the voices of the victims of terrorism as part of prevention efforts to counter radicalisation. One of the most important RAN policy papers on the victims, 'Handbook: Voices of victims of terrorism' (2015), drew ideas from the work of victims' organisations to argue that "European Remembrance day could be organised differently: more publicly, more open to the media, involving civil society (educators, youngsters, etc.), more national government officials and Members of the European Parliament. Also, Member States could be advised to organise, formalise and officialise a national Remembrance Day in cooperation with victim organisations" (RAN, 2015, 5).

In the aftermath of a conflict or violence, the role of victims' groups is fundamental for facts-finding, truth and justice demands, or restorative justice. This thinking is in line with the mainstream victimology literature that sees victims as the key to evidence-based policy and service delivery for trials, police investigation (Walklate, 2007; Lawter, 2005, 22). Given that these organisations ${ }^{19}$ emerge in response to a specific event, catching and maintaining the public and political interest for their plea becomes a major challenge over time. Most of these organisations disappear as they tend to lose support or public interest. The funding is also a major challenge for the financing of their activities as they are tied to donations and access to public funding. ${ }^{20}$

\footnotetext{
19 We use the term 'victim organisations' to describe broadly many forms of representation of victims though but not limited to associations, self-help groups, support groups and interest groups.

20 For instance, examination of the statues of Belgian based V-Europe and Life4Brussels shows that main sources of their funding are membership fees. We were not able to ascertain other sources of funding, as their annual financial balance is not available (neither on their webpages nor in the Belgian Central Balance Sheet 15
} 
However, in Europe, a number of organisations endure over the years and have broaden their audiences and membership beyond initial scope, like the AVT in Spain. Another example is Brussels-based 'V-Europe', created in response to the attacks in Brussels (2016), and active in advocating for victims' rights to truth, justice and compensation (V stands for Victims, Veritas -truth, and Victory). Presently, these organisations dominate the public discourse in terms of victims' voices and advocates for their rights. They have strengthened their influence by drawing considerable attention to the perceived international reluctance to address the victims' needs.

At EU level, incorporating 'victims' voices' meant that victims are now seen as "the representatives of and ambassadors for public memory", "credible voices on the painful and human consequences of violent extremism and terrorism" (RAN, 2015,7). Hence, the central role in the overall planning and tailoring of EU approach to remembrance has been increasingly given to those who 'represent' victims - the victims' organisations. Besides the Spanish, other countries that suffered terrorist violence are now members such as France, Belgium, Germany, UK, Ireland, or Italy.

Whereas terrorism is not a novel phenomenon in Europe, before RAN there were only limited attempts at transnational networking and exchange of experiences between victims' organisations at EU level. For a number of reasons, this has changed radically over the last years. The security issue returned as top priority on the EU's agenda with heightened attention to external borders management and a significant increase in the number of terror attacks. The terrorist incidents across the EU have highlighted the importance of adopting a specific approach to treating victims of such attacks, including survivors and family members of deceased. While the number of new organisations of victims has grown exponentially, the RAN reconfirmed itself as a hub for exchange of experiences between the old and new associations.

Office). In terms of number of affiliated members, Life4Brussels has 550, while V-Europe counts 250 members. 
Some of victims' organisations have nowadays a substantial impact on policybuilding both nationally and at the EU level, like the Spanish AVT. On transnational level, these organisations (among others) advocate for the EC to acknowledge and support remembrance initiatives for strengthening of collective memory, social cohesion and democratic values. For instance, the Victims Support Europe, created in the late 1990s by a handful of practitioners and national associations, advocates and lobbies for rights of victims (not only of terrorism) at EU level and within EU institutions. As their mission statement reveals they seek to improve EU and international laws, through research and knowledge development and through capacity building at the national and local level. Organisations such as, for example, l'Association française des victimes $d u$ terrorisme (AfVT), which appeared in 2009, shaped the policy process and steered the agenda of the EC towards the Victims first approach. The result of these efforts by the AfVT and similar associations is that victims and their organisations are not only 'ambassadors of memory' at EU institutions but are managing now to foster a degree of ownership over European remembrance policy regarding terrorism.

Victims first: EU remembrance as a means to tackling victims' needs?

The adopted Victims first approach is part of a restorative measure that signals EU's and member states' recognition of victims and symbolic assumption of responsibility for harms suffered due to terrorism. This is reiterated also in the new EU Victims' rights strategy 2020-2025. The strategy draws from a policy paper $^{21}$ by the EP to identify recognition from the state and from the society as one of the salient specific needs of victims of terrorism - 'an attack against the State, society or values' (EC, 2019). For instance, the EU Victims' Rights Directive (2012) identifies some of the needs and required responses for people that fall victim to a crime: a) recognition, acknowledgment, protection; b) support - emotional, psychological, financial, legal or practical; c) access to justice and d)

21 European Parliament, "How can the EU and the Member States better help the victims of terrorism?", Policy department for Citizens' Rights and Constitutional Affairs, September 2017, available at; <http://www.europarl.europa.eu/RegData/etudes/STUD/2017/596805/IPOL_STU(2017)596805_EN.pdf>. 
compensation. In this view, memorialisation is identified as a key tool to political (and societal) recognition and support for victims in the aftermath of violence, and crucial for the healing process of individuals.

"Unlike in most other violent acts, the victim of terrorism was not personally attacked but as a symbol of the state and society. Lack of recognition from the state and from the society has negative impact on the healing process of victims of terrorism. Therefore, recognition should be associated with remembrance and commemoration" (emphasis added; EC, 2019, 21).

Still largely lagging behind a holistic approach towards reparations ${ }^{22}$ for victims of terrorism, the focus of restorative justice by the member states and the EU is predominantly on symbolic politics: establishing monuments, museums and organising commemorative ceremonies such as the EU Remembrance Day.

The EU Remembrance Day is a whole day event held in Brussels in the premises of EU institutions (except in 2020, when it was held in the premises of the UNESCO in Paris), with high ranking politicians, relevant member states' ministers, local authorities, first responders, law enforcement, victims and their organisations. Victims' associations, represented by the RAN RvT, provide bottom-up impulse for shaping the narrative of the terrorist attacks and the conception of a 'terrorism-inflicted victimhood' that structure this commemorative event. In line with the Victims first approach, the main goal is to ensure that the European day of remembrance has positive effect for both victims and the community. To achieve this objective the Commission's imperative is that EU remembrance of victims of terrorism is planned, organised and conducted in a sensitive way and in continuous consultation with those affected.

Institutional representatives, such as EU Commissioners, ministers and various experts of EU member states usually open up the main ceremony with a keynote speech that frames the theme of annual commemoration. For instance, in 2019, 'Standing together' as a motto illustrated collaboration between the EU, governments and victims in addressing their needs, but also a solidary memorial

22 European Union, 2019, Strengthening victims' rights: from compensation to reparation. For a new EU Victims' rights strategy 2020-2025, Luxembourg: Publications Office of the European Union. See e.g. Letschert, Pemberton and Staiger (2010) on Restorative Justice and needs of Victims of Terrorism. 
response of European societies in the aftermath of violence. To bridge political and social responses pictures of grassroots memorials were projected on a screen and some of the objects collected in the aftermath of Brussels attacks exhibited at the venue. ${ }^{23}$ The day of remembrance is also used to provide reassurance for the victims on EU security agenda and protection of victims' rights. Institutional representatives, therefore, offer responses on national and European policies on counterterrorism, illustrating initiatives taken to prevent further violence and tackle consequences of prior attacks. In 2019, of particular attention for the victims was a report presented by Joëlle Milquet, a Special Adviser for compensation to victims of crime. The Special Adviser was appointed in late 2017, by the EC President Jean-Claude Juncker, to prepare a report on how to improve access to compensation for victims of crime.

The role attributed to the victims at this ceremony is testimonial. Selected by the RAN and their organisations, victims are coached to deliver 'suitable' testimonies in a sensitive manner. Before explaining what a 'suitable' testimony is, and what is its role in the remembrance event we must emphasise the following. First, not all the victims (or persons describing themselves as survivors) are members of victims' associations, and not all the victims wish to share their personal experiences in a public manner. Therefore, the victims' organisations are in a privileged, 'gate-keeper' position to shape the narratives and meanings assigned to memorialisation process. Moreover, they are in a position to discuss the possibility of delivering such a testimony in emphatic, direct contact with the victim - considering his or her personal situation. Second, the role given to testimonies and their presumed effects can be quite different for those who provide and receive them. Sometimes the victims of terrorist attacks provide a testimonial in order to increase awareness of the violence suffered, to inspire sympathy, or a positive change. ${ }^{24}$

Alluding to the therapeutic psychological value for the individual, and the catharsis effect of testimonials for the collective is a moot point, and beyond the

23 On the conservation/patrimonialisation of post-terror attacks memorials and their uses for commemorative ends, see Milošević (2018a), Bazin and Van Eeckenrode (2018) and Gensburger (2019).

24 Interview with Estefania Vera, the victim of terrorism (Author 1), 10 March 2020, Paris. 
scope of this analysis. However, in the opinion of the EC, testimonies could and should be used to signal positive resilience, prevent further radicalisation and to convince people to reject violence (see RAN, 2018,1). For instance, the first testimony at the 2019 commemoration was given by one of the Madrid bombings' victims: "When I was asked to talk about what these attacks meant for me I thought of my $67 \%$ disability, absolute incapacity to work", "how these attacks made me forget I even had the children because of the blood clots on my brain" (Esther Saez, 2019). Her testimony ${ }^{25}$ was based on coming to terms with the violence suffered: from waking up at the emergency ward, to learning how to cope with its consequences. In her words, this 'internal journey' is about learning how 'to ride upstream' and 'carry on' by deciding to understand, forgive and be positive.

Despite often assumed linear association between revealing and healing, telling and hearing to reaffirm the rule of law and help prevent future cultures of violence, we still know little of the effectiveness of testimonies in the prevention of terrorism. While the overall objective of organisations is to keep the public eye on their enterprise and plight, practitioners hope to generate empathy between the audience and the victims. However, a recently ran survey by the RAN RvT (2019) reveals that victims attending the event in Brussels see EU commemoration predominantly from a social identity perspective. The Remembrance event in Brussels is, hence, seen as an opportunity to bond with other victims and exchange ex-post experiences. The vast majority of survey respondents (2019) revealed that they are very satisfied with the logistics of the event: travel, accommodation and the meeting venue of the event (Albert Borschette Congress Center). The same goes for the official ceremony and its day long programme. Opinions were slightly different concerning the informal meeting, made the day before the ceremony and imagined as a "safe place" ${ }^{26}$ for victims to meet and network. Overall, $75 \%$ of respondents saw the EU Remembrance Day as an

25 As a non-written rule, testimonies given at EU event often vary in terms of selection of the victims and their experiences: from first responders, eyewitnesses, to third generation family members and survivors of attacks that took place outside Europe.

26 In our understanding a 'safe place' is not only a physical space providing the sense of security, but also a place that provides the victims with an opportunity to freely express their feelings before empathic peers, professionals or an audience. 
opportunity to meet the other victims, while $43 \%$ of them used the venue to meet and discuss with EU and MS representatives (RAN, 2019, 2).

Feedback on the attended event proved to be very useful for the RAN RvT especially in terms of addressing specific concerns or issues: such as for instance overall success of the event or more practical concerns as wheelchair accessibility at the venue. Unfortunately, no questions were included on the ceremonial aspect of the event and rituals that were enacted. Aside from speeches, minutes of silence and testimony giving by the victims and some of the first responders, the ceremony usually features numerous songs sang by the pupils' choir of the European school in Brussels. Over the last years, a tree had a special role to play in the ceremony: to symbolise growth and healing. In line with Heath-Kelly's observation (2018) across different cases, 'the EU tree' follows the trend of European and American memorials that increasingly appeal to the aesthetics of 'nature' to symbolize collective trauma and resilience after terror attacks. Resilience building - "the ability to bounce back and to find a new balance in life after a dramatic incident has occurred" (RAN) - is therefore projected as a desired outcome of the EU Remembrance Day for victims of terrorism. To an extent imposed by the way of framing the commemorative event, resilience building objective is enacted through use of rituals. Previous commemorations, for instance, included the ritual of throwing pebbles. In psychology and traumatology ${ }^{27}$ throwing pebbles has a symbolic meaning of 'letting go'. Other past commemorations focused on the audience coming together while lighting (battery operated) candles in a dark room - a ritual aiming to symbolise remembrance itself and memory as a light in the darkness.

\section{Competing influences: National and European levels of Remembrance}

Promoting and commemorating the EU Remembrance Day beyond countries that dealt with terrorism has been one of the most important challenges for the EU policy makers since its adoption in 2004. While the EU Remembrance day has always been essentially observed in Spain and inside EU institutions, the event 
held each year in the EP and then the EC evolved from being mainly focused on the remembrance of the 2004 Madrid bombings to encompass recent and less recent terrorist experiences of other states such as $\mathrm{UK}^{28}$, Germany, Belgium and in particular France.

The EU's memory framework and its soft laws prescribing EU commemorations are not legally binding for member states, even though they are invited to adhere to commonly forged mnemonic frames of reference. Thus, EU Remembrance Day is inclusive - as it is conceived as a joint expression of attitudes of all member states. But it is also exclusivist, as those who assign meanings and values to memorialisation are those countries that have similar experiences in terms of victimhood. What our analysis points out is therefore the prevalence of domestic context over European. On the one hand, countries opt among these aspects of Europeanised memory for what fits their interests and matches their experiences. On the other, they also make an attempt at uploading them to EU level with an aim of supporting political objectives pursued on domestic level.

This is exemplified with the French case. In 2018 it became evident that the French government and in particular the President Emmanuel Macron were to position themselves as leaders in terms of symbolic recognition for victims of terrorism, although France had hitherto demonstrated very little interest in the EU Remembrance Day created for them. At the EU ceremony in 2019, Élisabeth Pelsez, Interministerial Delegate for Victims' Assistance of France listed what specific initiatives were underway or undertaken already to integrate French experience with terrorism in national memory politics. Macron pledged to create a national memorial museum and a recognition medal ${ }^{29}$, given to the French and foreign victims of the attacks on French soil (inspired by the Royal Order of Civil Recognition for Victims of Terrorism in Spain, created in 1999). Pelsez also emphasised the importance of having "a register of all people affected by terrorism" so that their names "will not be erased" in history (2019).

28 Brexit poses a major challenge for the victims' associations from UK and Ireland. It remains unclear whether UK victims can still take part in the Remembrance Day after 2020.

29 The medal is given also retroactively to the victims of terrorism since 1974. 
The most important symbolic initiative, however, concerns the installing of the national day of tribute and remembrance of victims of terrorism mentioned previously. Considering French experience with terror attacks in recent years, a deliberate political choice has been made to incorporate these memories into national commemorative calendar. As we already said, the choice of March 11 has been motivated by the desire to be "fully in line with EU dimension of remembrance" in order "to symbol unity and allegiance that goes beyond national borders", in the words of Pelsez (2019). But French politicisation of remembrance threatens to overshadow EU's commemoration. The experience with the 2020 events in Paris illustrates this clearly: the EU's know-how provided a sort of template to emulate and download into national commemorative calendar. And at the same time, a clear hierarchy is installed: national comes over European, as the French victims with their own special day and status receive greater consideration in this ceremony than other victims in other European countries.

While France positioned itself as a strategic memorial actor, Belgium also made attempts at transnationalising memory of recent terror attacks. In Belgium where terrorist attacks struck the capital in March 2016, the government made a deliberate choice not to install a monument at the places where the bombings occurred, at the Maelbeek metro station and Zaventem Airport. Instead a monument to 'all the victims of all terror attacks' is placed at a neutral location: the EU quarter - a zone where all major EU institutions are situated in Brussels. Previous studies based on interviews with the victims and their associations have argued that such 'a neutral location' has alienated many victims and the general public (Milošević, 2018b, 2019), which is often the case when a memorial for the victims of a terror attack is disconnected from the scene of the attack (Truc, 2012b; Truc, 2017; Heath-Kelly, 2017). The Belgian attempt at transnationalising and hence Europeanising a national memory is, arguably, motivated by the domestic policy of depoliticizing the consequences of terrorism and hence opting for an apolitical approach to remembrance.

The official national commemoration of Brussels attacks, on March 22nd, covers visits to places of atrocity and finishes with a wreath laying ceremony by the Prime Minister at the monument in EU quarter. However, the EU 
commemorations on March 11 do not make use of the Brussels monument although it has been made in remembrance of 'all victims'. The invitees to the EU commemoration are informed about the monument with a memo, yet an organised visit to the memorial makes no part of the official EU ceremony. The choice of whether or not to visit the memorial relies solely on the individuals. Within a random sample of interviewed victims that attended 2019 commemoration, none has visited the monument. ${ }^{30}$ However, some of the victims' organisations (predominantly Brussels-based) made visit organised by the Victim Support Europe's board and representatives from 8 countries. The ceremony was coorganised by V-Europe and the White March Committee to pay tribute to all victims of terrorism (The Portuguese Association for Victim Support (APAV), 2019).

Taken together these findings suggest that not only the EP has been sidelined as a mnemonic actor, but that member states use EU memory framework as a template to download and adapt to their own experiences, needs and objectives. As such, both national and EU remembrance days for the victims of terrorism appear today as political tools to underpin a wide range of policies and objectives (e.g. security, counterterrorism, political legitimacy) and not simply symbolic acts directed to the acknowledgement and attainment of victims' needs.

\section{Conclusion}

On the afternoon of March 11th in Paris, we found ourselves on the opposing sides of the Trocadero square where the French Remembrance Day was taking place for the first time. A political scientist (Author 1) sitting two rows behind the French president and the Spanish King, surrounded by victims from Spain, Belgium and Germany that have already assisted the morning EU commemoration. A sociologist (Author 2), behind a fenced line of a blocked district, circulating among its disoriented residents ("But why did they close all the streets?", "What do you mean the subway station's closed?"...) and police officers giving them confusing explanations ("it is for the anniversary of the Madrid attacks", "'it is because the Spanish King is here", "it is a ceremony for

30 Field notes (Author 1) March 2019. The victims were approached during the ceremony that gathered around 250 victims, families, associations, national and EU representatives. 
the victims of terrorism"...) that left them with more questions than answers ("But why are they doing this here? There had been no terror attacks in this neighbourhood...").

Overlooking the Eiffel tower, both of us were asking ourselves and each other (through text messages) a different set of questions, not only about our own positionalities and the risks involved in organising a high-profile event amidst the COVID-19 crisis - but also about the motivations for and purposes assigned to such a public remembrance. What makes a commemoration truly European? What role shared experiences play in this process of transnationalising memory and for whom? And finally, who are the audiences of this ceremony after all? The victims themselves, the French society, international media outlets? Because what is the sense of holding a memorial ceremony for victims of terrorism when the general public is kept as far away from it as possible? At the same time, could it be otherwise?

Over the last 15 years the European Union has been annually observing the Day of Remembrance for victims of terrorism. Whereas the initial policy building impulse for the creation of such a commemorative event came from the European Parliament, its role in commemorative ceremonies has faded over time to become purely representative. Instead, the ownership over the event, its underlying narratives and values assigned to it shifted entirely to the European Commission. By analysing the EU day of remembrance for victims of terrorism, this article argued that despite the attempt at transnationalising experiences of member states and victims of terrorism, there is little evidence to suggest that this event is truly "European". Until very recently, it was essentially a Spanish affair: created under the influence of the ETA victims' lobby, and set at the date of the worst attack in Europe, admittedly, but above all in Spain. And even if there is now also a French commemorative event on that date, arguably, the European dimension, reach and impact of this Remembrance Day appear even weaker.

The powerful connection between nationhood and commemoration is seemingly unaffected by transnational governance. As we have shown, the EU institutions, national governments, victims' associations and their representatives - all assign their own purposes to the remembrance of victims of terrorism. Commemorating 
jointly serves to reinforce the strength of political alliances and friendships, it pacifies tensions and provides sense of security through promises of nonreoccurrence and accountability. As such the EU Remembrance Day for victims of terrorism pursues a broad range of objectives which are not always linked to the meanings and experiences of victims themselves, specifically when these latter are not members of one of the associations involved in this European memory policy. Its general framing evolved from a recall of the 'European solidarity' in front of terror and of the 'sacrifice' of the victims for the 'European values' to a contribution to counter-radicalisation, prevention of violence, and social resilience. This suggests that, similarly to the other post-conflict or postviolence situations, symbolic politics are often a surrogate for (f)actual responses to victims' needs such as right to truth or compensation. Real value of symbolic politics, as we showed, lies within its mobilizing potential.

\section{Bibliography}

Anderson, Benedict (2006 [1983]), Imagined communities: reflections on the origin and spread of nationalism, London, Verso.

Bali, Valentina A. (2007), "Terror and elections: Lessons from Spain”, Electoral Studies, vol. 26 (3), p. 669-687.

Bazin, Maëlle and Van Eeckenrode, Marie (eds) (2018), Mise en archives des réactions post-attentats : enjeux et perspectives [numéro thématique], La Gazette des archives, vol. 250.

Bigo, Didier, Bonelli, Laurent and Deltombe, Thomas (eds) (2008), «Au nom du 11 septembre... Les démocraties à l'épreuve de l'antiterrorisme », Paris, La Découverte.

Bonelli, Laurent (2005), «Un ennemi «anonyme et sans visage». Renseignement, exception et suspicion après le 11 septembre $2001 »$, Cultures \& Conflits, vol. 58 (2), p. 101-129.

Calligaro, Orianne and Foret, François (2012), «La mémoire européenne en action. Acteurs, enjeux et modalités de la mobilisation du passé comme ressource politique pour l'Union européenne », Politique européenne, vol. 37 (2), p. 18-43.

Chueca, Miguel (2012), «Les attentats du 11 mars 2004 à Madrid et les "théories de la conspiration" », Agone, vol. 47, p. 105-143. 
Connerton, Paul (1989), How societies remember, Cambridge, Cambridge

University Press.

European Parliament (2008), "Commemoration of the Holodomor, the artificial famine in Ukraine (1932-1933)”, P6_TA(2008)0523, Strasbourg, 23 October, <https://www.europarl.europa.eu/sides/getDoc.do?type=TA\&reference=P6-TA2008-0523\&language $=\mathrm{EN}>$.

European Parliament (2015), “Armenian genocide 100th anniversary", P8_TA(2015)0094, Brussels, 15 April, <https://www.europarl.europa.eu/doceo/document/TA-8-2015-0094_EN.html>.

Gensburger, Sarah (2019), Memory on my doorstep. Chronicles of the Bataclan neighborhood, Paris 2015-2016, Leuven, Leuven University Press.

Gensburger, Sarah and Lavabre, Marie-Claire (2004), «Entre 'devoir de mémoire' et 'abus de mémoire' : la sociologie de la mémoire comme tierce position », in Bertrand Müller (éd.), Histoire, Mémoire et Épistémologie. Autour de Paul Ricœur, Lausanne, Payot, p. 76-95.

Gensburger, Sarah and Lavabre, Marie-Claire (2012), «D’une «mémoire» Européenne à l'européanisation de la «mémoire»», Politique Européenne, vol. 37 (2), p. 9-17.

Gensburger, Sarah and Lefranc, Sandrine (2020), Beyond Memory. Can we really learn form the past?, New York, Palgrave.

Guittet, Emmanuel-Pierre (2006), «'Ne pas leur faire confiance serait leur faire offense'. Antiterrorisme, solidarité démocratique et identité politique », Cultures \& Conflits, vol. 61 (1), p. 51-76.

Heath-Kelly, Charlotte (2017), Death and security. Memory and mortality at the bombsite, Manchester, Manchester University Press.

Heath-Kelly, Charlotte (2018), "Survivor Trees and memorial groves: Vegetal commemoration of victims of terrorism in Europe and the United States", Political Geography, vol. 64, p. 63-72.

Hoffman, Bruce and Kasupski, Anna-Britt (2007), "The Victims of Terrorism: An Assessment of Their Influence and Growing Role in Policy, Legislation, and the Private Sector", Policy paper, Santa Monica, RAND Center for Terrorism Risk Management Policy. 
Letschert, Rianne, Pemberton, Antony and Staiger, Ines (eds) (2010), Assisting Victims of Terrorism: Towards a European Standard of Justice, Dordrecht, Springer.

Levy, Daniel and Sznaider, Natan (2002), "Memory Unbound: The Holocaust and the Formation of Cosmopolitan Memory", European Journal of Social Theory, vol. 5 (1), p. 87-106.

Littoz-Monnet, Annabelle (2012), "The EU Politics of Remembrance: Can Europeans Remember Together?”, West European Politics, vol. 35 (5), p. 11821202.

Lynch, Orla and Argomaniz, Javier (eds) (2015), Victims of Terrorism. A comparative and interdisciplinary study, Abingdon, Routledge.

Manners, Ian (2010), "Global Europa: Mythology of the European Union in World Politics”, Journal of Common Market Studies, vol. 48 (1), p. 67-87.

Milošević, Ana (2017), "Remembering the present: Dealing with the memories of terrorism in Europe", Journal of Terrorism Research, vol. 8 (2), p. 44-61.

Milošević, Ana (2018a), "Historicizing the present: Brussels attacks and heritagization of spontaneous memorials", International Journal of Heritage studies, vol. 24 (1), p. 53-65.

Milošević, Ana (2018b), "Can memorials heal the wounds?", Observing Memories, vol. 2, p. 56-63.

Milošević, Ana (2019), "European Commemoration of Vukovar. Shared memory or joint remembrance?", in Vjeran Pavlaković and Davor Pauković (eds), Framing the National and Collective Identities. Political Rituals and Cultural memory of the Twentieth-Century Traumas in Croatia, London, Routledge, p. $225-240$.

Milošević, Ana and Touquet, Heleen (2018), "Unintended consequences: the EU memory framework and the politics of memory in Serbia and Croatia", Southeast European and Black Sea Studies, vol. 18 (3), p. 381-399.

Milošević, Ana and Trošt, Tamara (eds) (2020), Europeanisation and Memory Politics in the Western Balkans, New York, Palgrave Macmillan.

Monar, Jörg (2009), «La mise en œuvre de l'espace de liberté, de sécurité et de justice: un défi pour l'Union Européenne et pour les États membres », Revue française d'administration publique, vol. 129 (1), p. 15-34.

RAN (2015), Handbook: Voices of victims of terrorism, $<$ https://ec.europa.eu/home-affairs/sites/homeaffairs/files/what-we- 
do/networks/radicalisation_awareness_network/about-ran/ranrvt/docs/ran_vvt_handbook_may_2016_en.pdf $>$.

RAN (2018), "Delivering Effective Testimonials", RAN ex post paper, RAN RvT Working Group, Amsterdam, 20-21 September, <https://ec.europa.eu/homeaffairs/sites/homeaffairs/files/what-we-

do/networks/radicalisation_awareness_network/about-ran/ran-

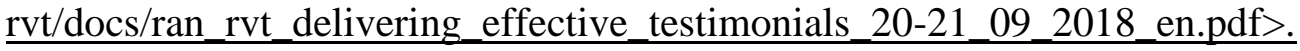

Reinares, Fernando (2017), Al-Qaeda's Revenge: The 2004 Madrid Train Bombings, New York, Columbia University Press.

Rosoux, Valérie (2003), «Mémoire(s) européenne(s) ? Forces et limites de l'intervention politique dans la mise en scène de l'histoire », Politiques et sociétés, vol. 22 (2), p. 17-34.

Truc, Gérôme (2012a), «Aux victimes du terrorisme, l'Europe reconnaissante ? Portée et limites de la Journée européenne en mémoire des victimes du terrorisme », Politique européenne, vol. 37 (2), p. 132-154.

Truc, Gérôme (2012b), "Memory of places and places of memory: for a Halbwachsian socio-ethnography of collective memory", International Social Science Journal, vol. 62 (203-204), p. 147-159.

Truc, Gérôme (2017), «Quel mémorial après un attentat de masse ? Trois capitales européennes face au même défi mémoriel », Mémoires en jeu, vol. 4, p. $90-95$.

Truc, Gérôme (2018), Shell Shocked. The Social Response to Terrorist Attacks (Andrew Brown, trad.), Cambridge, Polity Press.

Truc, Gérôme (2019), "What terror attacks do to societies: Fieldwork and case studies", Ethnologie française, vol. 173 (1), p. 5-19.

Truc, Gérôme and Sánchez-Carretero, Cristina (2019), "Polarised topography of rival memories: the commemorations of the 11th March 2004 train bombings in Madrid”, in Marie Louise Stig Sørensen, Dacia Viejo Rose and Paola Filippucci (eds), Memorials in the Aftermath of Armed Conflict: From History to Heritage, New York, Palgrave Macmillan, p. 33-60. 
Walklate, Sandra (éd.) (2007), Handbook of victims and victimology, Cullompton, Willan.

Ana Milošević is a Post-Doctoral Researcher at the Leuven Institute for Criminology (LINC) at KU Leuven. She completed a PhD on Europeanisation of memory politics in Croatia and Serbia, and has published extensively on collective memories, identities and European Integration of post-conflict societies with a special focus on coming to terms with the past. Her current research examines the roles assigned to memorialisation processes in relation to terrorism with a view to critically assess their effectiveness for the victims, survivors and societies at large.

Gérôme Truc is a sociologist, tenured research fellow at the French National Center for Scientific Research (CNRS) and member of the Institut des Sciences sociales du Politique. His work focuses on social responses to terrorist attacks and their memorialisation, mainly in western societies. He leads the REAT research project, supported by the CNRS, and he is a board member of the interdisciplinary "13-November" research program. He is the author of Shell Shocked: The Social Response to Terrorist Attacks (Polity Press, 2018). 